\title{
The mnemonic transition: The rise of an anti-anticolonial memoryscape in Cape Verde
}

Memory Studies

$1-15$

(C) The Author(s) 2020

Article reuse guidelines: sagepub.com/journals-permissions DOI: $10.1177 / 1750698020927735$ journals.sagepub.com/home/mss

(\$SAGE

\author{
Miguel Cardina \\ and Inês Nascimento Rodrigues 1 \\ Centre for Social Studies of the University of Coimbra, Portugal
}

\begin{abstract}
This article analyses the production of an anti-anticolonial memoryscape in Cape Verde in the 1990s. We will show how this process is bound up with a mnemonic transition that accompanied the economic and political transition taking place in the country and also marked by changes occurring internationally in the wake of the fall of the Berlin Wall and the global expansion of multipartidarism. Proposing a broadening of the concept of memoryscape, we will examine the alterations produced in the public space, in the national symbols and in the valorization of events and personages that have marked the history of the archipelago. We find that they produce a mnemopolitical imaginary different from the anticolonial legitimacy that had emerged from a victorious liberation struggle against Portuguese colonialism and became hegemonic immediately after independence (1975-1991).
\end{abstract}

\section{Keywords}

Cape Verde, hegemonic memory, liberation struggle, memoryscape, mnemonic transition, postcolonial

\section{Introduction}

Hamzah Muzaini (2014) considers that 'as political regimes undergo transformational changes, so do memorial landscapes established by or previously associated with them' (p. 142). Although the theme of memory is increasingly considered in the study of political transitions, less attention has been given to processes of mnemonic transition and their role as both cause and effect of the dynamics redefining relations between politics, nation and power. In fact, political transitions are often accompanied by corresponding mnemonic transitions, whose periodization and reach show a clear interconnection, despite their relative autonomy.

This article takes as reference the case of Cape Verde and the adoption of the multi-party system after 1990/1991. We will try to illustrate how the nature of the political transitions - their forms, rhythms and contents, their successes, limits and impasses - makes it necessary to include in the

\section{Corresponding author:}

Miguel Cardina, Centre for Social Studies, University of Coimbra, Colégio de S. Jerónimo, Largo D. Dinis, Apartado 3087, Coimbra 3000-995, Portugal.

Email: miguelcardina@ces.uc.pt 
analysis the transformations in the national memoryscapes produced at the same time by the political elites, and their role in the construction of a new hegemony. We will explore in detail how the mnemonic transition consisted of the production, in the 1990s, of a new imagetic-memorial landscape, here called anti-anticolonial, posited as an alternative to the memoryscape constituted in the wake of independence, which valorized the liberation struggle against Portuguese colonialism.

The term 'memoryscape' is now widely used in memory studies as a synonym for the mnemonic place occupied by museums, squares, statues and other material objects (Davis, 2013; De Jong, 2008; Edensor, 1997; Kappler, 2017; Muzaini, 2006; Muzaini and Yeoh, 2016). ${ }^{1}$ Here, we will argue for a broader perspective, which does not only merely focus on materializations of memory in concrete physical and territorial spaces but also attempts an integrated analysis of the materiality, politics and social imaginary involved in the composition of memoryscapes. Our focus is predominantly on the role played by the state in the production of these memorial complexes, stimulating sociopolitical dynamics connected with the monuments, symbols and discursive devices that integrate them and give them cohesion, and we also consider their interaction with civil society. The study is based on interviews, observation visits and extensive archival material collected during field work carried out in Cape Verde between 2018 and 2019. In this article, we will begin by explaining the specificity of the process of political independence of Cape Verde; then, we will give a general overview of the memoryscape produced during the regime of "national revolutionary democracy', and finally, we will examine the mnemonic transition and production of a new memoryscape in the 1990 s, as well as its cycles, reasons and functionalities.

\section{Cape Verde and the place of the liberation struggle}

Cape Verde is an archipelago made up of 10 islands, located 350 miles from Senegal. Initially uninhabited, Cape Verde - particularly Santiago island - was used from the fifteenth century as an important entrepôt for enslaved people from the west coast of Africa, who would then be sent across the Atlantic to Europe and the Americas. This history of slavery, bound up with the gradual emergence of a Creole elite, marked the racial composition of Cape Verdean society. The particular position fulfilled by the archipelago in the context of the Colonial State in the Portuguese Empire also determined (again from those elites) the ways in which Cape Verde's different identity was imagined. ${ }^{2}$ The image of Cape Verdean exceptionality would thus be marked by the combination of two dominant archetypes: Europe (or Portugal, the colonizing metropolis), symbolizing reason, paternity, culture and knowledge; and Africa, the place of emotion, maternity, tradition and disorderliness (Anjos, 2004; Cidra, 2018; Monteiro, 2016; Rego, 2015; Vasconcelos, 2004).

The territory became independent from the Portuguese Colonial Empire in 1975 after the long armed struggles for independence (1961-1974) that took place in Angola, Mozambique and Guinea. Led by the charismatic figure of Amílcar Cabral, the struggle of the PAIGC (African Party for the Independence of Guinea and Cape Verde) was the most successful, not only because it managed to control a substantial part of the Guinean territory but also because of the sympathy it attracted internationally. The first attacks carried out in 1963 were followed by a series of political decisions, military actions and diplomatic successes, culminating in the unilateral declaration of independence of Guinea in September 1973, months after the assassination of Cabral in Conacry. ${ }^{3}$ The defeats and setbacks of the long colonial war led a group of middle-ranking officers to stage a military coup in Portugal on 25 April 1974, which rapidly transformed into a socialist-style revolution, accompanied by the independence of the African colonies. In Cape Verde, independence was formally recognized on 5 July 1975, ending a period of around a year in which popular mobilization related to the PAIGC in the islands consolidated its hegemony, warded off other political 
movements and created conditions for the new Cape Verdean leaders to be acclaimed as the ruling heads of the State (Almada, 2012; Coutinho, 2015; Furtado, 2016; Lopes, 1996).

Thus, the armed struggle which led to the independence of Cape Verde had the particularity of having been fought in Guinea for the liberation of both territories, reflecting the common history they had shared since the times of slavery. Some Cape Verdeans took part in the armed anticolonial struggle in Guinea; others worked clandestinely from Cape Verde itself; still others went into exile in Europe or Africa, where they became involved in diplomatic and political actions (Lopes, 1996). For the most part, the liberation struggle was waged outside the territory, which would later determine the specific ways in which the event was recalled, interpreted and inscribed. In the immediate post-war context, this produced a (not always uncontested) memoryscape of the struggle composed of discursive, symbolic and political spaces, in which the valorization of that revolutionary past plays a central role.

In fact, in the first 15 years of independence, under the government of the First Republic, political legitimacy and symbolic recognition were conferred by participation in the liberation struggle and which extended to the movement that had led it, the PAIGC. ${ }^{4}$ For various reasons, its leader Amílcar Cabral, the great strategist of the struggle against Portuguese colonialism, with a remarkable international standing that still persists today, was credited as the greatest figure of the nation. Assassinated before independence, he emerged as a martyr figure, as well as a theorist who brought to bear upon the struggle a cluster of broader teachings of a cultural, social and political nature.

Amílcar Cabral was a constant presence in this period. He appeared in the Cape Verdean songbook and on commemorative stamps and was mentioned as an example to follow in the 5 July celebrations. The newspaper Voz di Povo regularly published excerpts from his writings, speeches and interviews, and the preamble of the 1980 Constitution mentions him as the 'founder of the nationality'. In 1983, the Amílcar Cabral Symposium was organized in his homage, and on 12 September of the following year, the Amílcar Cabral Foundation was inaugurated, among other examples. Then in 1987, the famous Brazilian architect Óscar Niemeyer designed a cultural centre to be dedicated to his memory, though this was never actually built. ${ }^{5}$

The freedom fighters that had fought at his side - particularly those with direct combat experience in Guinea, many of whom members of the new governing body - functioned as a moral repository of the legitimacy of the country. A significant section of the recent political elite and emerging bureaucracy resulted paradoxically from the investment in education made by the Republic, established in Portugal in 1910, and promoted from the 1950s onwards by Catholic congregations and, more decisively, by the expansion of the late colonial state (Barros, 2012). In allocating resources and broadening the public administration to restrain anticolonial sentiments that were raging both inside and outside the country, the late colonial state ultimately opened up the way for this new elite, legitimized by the struggle, which wanted to lead the nation (Barros, 2012; Barros-Varela, 2017; Furtado, 1997; Silva, 2001). Endowed with 'mnemonic hegemony' (Molden, 2016), its members became important agents in the construction of a mnemopolitical landspace after 1975, activating various products and practices of memory through which the process of conquering independence was brought into daily life and made meaningful (Paasi, 2016). The armed struggle emerged as the birth certificate of the postcolonial nation, simultaneously constituting itself as a great symbolic narrative of the return of Cape Verde to 'Africa', which would materialize through a project of binational union with Guinea-Bissau. ${ }^{6}$

The national symbols (flag, coat of arms, anthem) of Cape Verde are particularly expressive of this question. The national flag was virtually identical to the flag of the PAIGC and very similar to that of Guinea-Bissau. Consisting of three rectangular strips in yellow, green and red (colours that are emblematic of Pan-African ideals), it includes in its emblem two ears of corn, a shell and a 
black star. As for the national anthem ('This is our beloved fatherland'), shared with GuineaBissau, and with words by Amílcar Cabral, it not only praises the ancestors and the nation but also glorifies the liberation struggle and exhorts the people to overthrow colonial domination. ${ }^{7}$

With regard to the festive calendar, the following dates were, among others, defined as national holidays in 1976: 5 July, National Independence Day; 12 September, Nationality Day (marking the birth of Amílcar Cabral) and finally 20 January, National Heroes' Day (the date of his assassination). As regards the currency in circulation after independence (the Cape Verdean escudo), the image of Cabral was displayed on one side of all notes, with other African revolutionary figures adorning the coins. This homage was in line with the re-Africanization supported by the PAIGC and was also present in street names, music, ${ }^{8}$ political speeches and sporting competitions in the first years of independence. On the island of Sal, the airport was renamed 'Amílcar Cabral International Airport' and throughout the archipelago, public buildings, monuments, streets and squares acquired names associated with the liberation struggle.

This nationalizing of the memories of the struggle (particularly in a territory where there was no armed conflict) essentially served a nation-building role in the post-independence period, acquiring new relevance after the end of the binational unity with Guinea-Bissau, in 1980, which resulted in the creation, in the following year, of the African Party for the Independence of Cape Verde (PAICV). ${ }^{9}$ The First Republic (1975-1991) thus ended up producing and disseminating a memoryscape of the struggle as the cradle of the nation, that tends to be centred on the following axes: (a) the condemnation of the colonial system and the promotion of the history of Cape Verde's liberation; (b) the approximation of the archipelago to the African continent in political, cultural and identity terms; and (c) a symbolic grammar, which structured around values such as heroism, sacrifice and courage, ultimately giving the combatants-turned political agents a prominent position in the hierarchy of Cape Verdean society.

\section{The mnemonic transition in Cape Verde}

The political transition that occurred in Cape Verde in 1991 was preceded by a process of economic and political liberalization dating from the mid-1980s (Cahen, 1991; Évora, 2004; Koudawo, 2001; Sanches, 2018: 73-95; Silva, 1997). This period of latency was followed by the strict cycle of political transition, with the clear victory of the Movement for Democracy $(\mathrm{MpD})$ in the legislative elections of 13 January $1991 .{ }^{10}$ Victories in the presidential and local elections ensued. ${ }^{11}$ According to Koudawo (2001), 'the PAICV, which had initiated the economic reforms, would have carried them out in any case' (p. 159). The distinctive factor here was the clear espousal of a neoliberal philosophy on the part of the new elites, with economic and political liberalization bound up in the process.

In fact, it was the PAICV itself which, in 1988, established a model based on 'economic extroversion' and took steps towards pluralism, accelerated by domestic social pressure. Silva (2001) speaks of a contradiction in the PAICV:

it neither liberalized the economy to the point of allowing some of the petit-bourgeoisie to convert its cultural capital into economic capital nor maintained its welfare support quality to enable social aid to be given to peasants affected by the drought. (p. 67)

This partly explains the political openness. To this should be added the so-called 'Tocqueville paradox' (Silva, 2004): it was to some extent the success of the PAICV in education and the formation of new cadres which generated social demands that could not be satisfied. Koudawo (2001: 118127) also mentions, as causes of the transition, the international pressure, erosion of power and 
internal disputes within the party, as well as the role of a deep-rooted Catholic Church, which functioned as a kind of permanent semi-opposition and contestatory structure manifested at particular moments, such as during the agrarian reform in 1981 and the decriminalization of abortion in 1986.

The political transition was followed by what we call the 'mnemonic transition'. ${ }^{12}$ This involved the replacement of the dominant memorial landscape by a new memoryscape, which 're-arrange[d] the cultural coordinates of the broader community' (Molden, 2016: 131), erasing the centrality of the anticolonial heritage and the connection to Africa, and recuperating events and figures from before independence. In an international context marked by the fall of the Berlin Wall, criticism of single-party regimes and the global expansion of neoliberalism, ${ }^{13}$ those 'mnemo-hegemonic shifts' (Molden, 2016: 131) were an essential part of the construction of an emerging 'democratic legitimacy' which in that way designed a new imaginary for the nation.

It is important to notice that, after 1985, the political powers had already brought back to some cities in the archipelago the busts of prominent figures of Cape Verdean society during the colonial period and had already organized a symposium honouring the 'Claridade' movement, as they instituted the literary prize with the same name. ${ }^{14}$ In the wake of the 1991 elections, this process is expanded and redesigned with distinct political uses and the following purposes: to establish new national narratives, new national heroes and new State symbols. Thereby, one of the new government's first actions was to reinstate monuments from the colonial period. In March 1991, in fulfilment of an electoral promise, the statue of the Portuguese Diogo Gomes (one of the navigators believed to have landed on the island in the fifteenth century), which had been raised in 1958 but removed in the early hours of independence (Lopes, 1996: 23), was returned to its place near the presidential palace, in the capital city of Praia. Occurring the day before the new President of the Republic was due to take office, the action was applauded on the cover of the widest-circulation newspaper as 'emerging from clandestinity' (Raimundo, 1991). In S. Filipe, on the Island of Fogo, the bust of Serpa Pinto (a soldier who had played a role in putting down revolts against the Portuguese colonial presence in Africa, and a former governor of Cape Verde) also reappears in 1991 (Alves, 1991). On August 1992, the busts of Luís Vaz de Camões and the Marquis Sá da Bandeira returned to the centre of Mindelo, on the Island of S. Vicente, reoccupying their places in a square that had previously been named after Amílcar Cabral. ${ }^{15}$ In the same decade, the statue of another Portuguese discoverer, Diogo Afonso, returned to a prominent place in Mindelo.

In addition to the substitution of busts and statues, some street names were also changed, with the names of African leaders that had been attributed in the post-independence period now replaced with those formerly used in the colonial period. Górny and Górna (2019) studied this process in detail with reference to Platô, the institutional and symbolic heart of the city of Praia, where some of the streets and avenues that existed prior to 1974 were renamed in the post-independence period. After the 1990s, some of those names reverted, and today, of the 35 main roads in Platô, 31 directly evoke the colonial period, mostly with names of colonial statesmen, high-ranking military officers or governors. This fact led the authors to consider that, if the case of Praia was viewed against a general backdrop of the Global South, 'the return to a symbolism that so unambiguously recalled the colonial period was a phenomenon virtually unparalleled' (Górny and Górna, 2019: 1117). Still in the capital but outside the most affluent area, the neighbourhood known as the Bairro Craveiro Lopes, built in 1954 and renamed Bairro Kwame Nkrumah after 1975, recovered its original name in 1993, a reference to the Portuguese high-rank military and President of the Republic between 1951 and 1958.

At the same time, there was a public backlash against the PAIGCCV and those combatants that had occupied important political positions during the single-party regime. ${ }^{16}$ The struggle, particularly its armed manifestation, has its foundational and symbolic place diminished, replaced by 
another narrative about the nation's origins. One of the features of this novel reading of the past is that Cape Verde's independence is generally seen as a historical inevitability, that is, not as a direct result from the liberation struggle, but as a by-product of an international context favourable to the self-determination of peoples.

The PAIGC/CV's attempts to make Cabral a national symbol through the media, political speeches, songs and public ceremonies were followed, in the years of the mnemonic transition, by what we call a process of de-Cabralization: his effigy disappeared from the notes and coins, his birthday was no longer celebrated as a national holiday, and the anthem that he wrote was replaced. The process of de-Cabralization coexisted with a series of actions against the "combatants of Guinea', who were described in newspapers as corrupt oppressors (e.g. Santos, 1991b). ${ }^{17}$ In this context, there were also changes in the awarding of the Medal of the Amílcar Cabral Order, the highest honour granted by the Cape Verdean state, instituted in $1987 .{ }^{18}$ The first president, Aristides Pereira, awarded the medal to 47 Cape Verdean combatants in the space of around a month (22 December 1990 and 19 January 1991), most of them commanding officers of the Revolutionary Armed Forces of the People, the armed wing of the PAIGC, for the services provided during the struggle. During the following 10 years of the presidency of António Mascarenhas Monteiro, the honour was awarded seven times and exclusively to foreign political leaders. ${ }^{19}$

Alongside this, the status of the Liberation Struggle Combatant (Combatente da Liberdade da Pátria) was broadened in 1991, resulting in a considerable increase in requests for recognition over the course of the decade. ${ }^{20}$ While in the first years of independence, most of those recognized as combatants had been involved in armed conflict in Guinea, the changes introduced to the legislation in the 1990sallowed other forms of participation in the struggle to be included, beyond the direct engagement on the war. ${ }^{21}$ It was also no longer necessary for a membership on the ranks of the PAIGC, which diminished the symbolic worth of the historical combatants and indeed of the armed conflict itself in the history of the nation's birth.

The struggle as a whole, however, could not be completely denied as national historical heritage, not only because of the international recognition given to the liberation process but also because the elites that were now in power derived their symbolic capital partially from the struggle. In fact, the founding members of $\mathrm{MpD}$, the party that won the elections in 1991, included an influential group that had been PAIGC dissidents in the post-independence period and whose participation in the struggle was mainly political and carried out in Portugal and other destinations of Cape Verdean emigration. In an operation that was openly antagonistic to the historical leaders, they presented themselves as double combatants: liberation combatants, on the grounds that they had taken part in the struggle for national independence, and - more importantly in this context - as combatants for democracy. Indeed, they claimed that the 'true' liberation of the archipelago was not achieved until 1991, through their incentive and pressure.

This mnemonic transition established a new paradigm for the commemoration of the struggle and the nation. In this political, economic and social context, a different memoryscape was created which reflected, in some aspects, the desire for a break with the legacy of the armed struggle and the icons forged by the previous regime. What is more, the 'democratic opening-up again institutionalizes the Creole identity as the essence of the Cape Verdean nation' (Anjos, 2004: 286). It was in this framework that the discourse of Cape Verdean exceptionality gained fresh impetus, with a reinvigorated emphasis upon the 1930s heritage of the Claridade and on those aspects of the Cape Verdean identity that were supposedly derived from a Portuguese matrix. It was accompanied by a process of substituting the national symbols. A committee was created for the purpose, in which the PAICV refused to participate.

As for the new flag, chosen from 64 proposals received in a contest and hoisted for the first time in September 1992, the visual proximity to the flags of Guinea-Bissau and PAIGC disappeared, as 


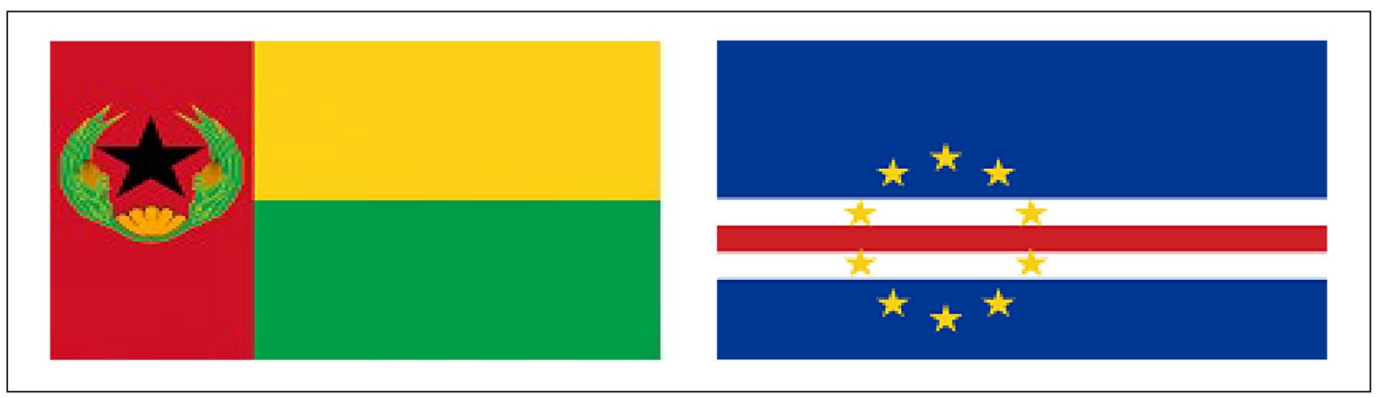

Figure I. Cape Verdean flags after independence: the first (1975-1992) and the current one. Source: National Assembly of Cape Verde, http://www.parlamento.cv/simbolosnacionais/index.html (accessed 3 February 2020).

did the reference to the colours associated with Pan-Africanism, still seen in the flags of many African countries. ${ }^{22}$ With a graphic design and colour scheme that, for many people, echoes the flag of the European Union (EU) (Madeira, 2018: 168; Rego, 2015: 72), the change is a clear sign of the new political, strategic and economic alliances that were forming in the country, with Portugal, and Europe in general, heading the list of privileged partners of Cape Verde for foreign investments and/or private enterprises in a context of a strong economic liberalization (Figure 1).

The architect responsible for the winning proposal (who was accused of anti-Africanism at the time) denied that he had been inspired by the EU flag. Instead, he insisted, the 10 equidistant yellow stars represented the 10 islands of the archipelago, all of equal importance, while the blue of the background evoked the colour of the sea and the sky that were so much part of the daily lives of Cape Verdeans. ${ }^{23}$ The symbolism of the new flag thus gestures towards the massive Cape Verdean diaspora and its potential for international cooperation; the people's vocation for migration; and the country's geostrategic position in Macaronesia (composed of the Azores, Madeira, the Canaries and Cape Verde).

The change of flag was hotly contested and there were intense parliamentary and media debates about the matter in 1991 and 1992. Demonstrations took place in Santiago and S. Vicente, the two biggest islands of the archipelago, and also in the diaspora, for instance, in the United States; a petition in support of the old flag containing around 25,000 signatures was presented to the parliament; and the PAICV proposed a referendum, which was ultimately rejected by the party in power, alleging that the people, when they voted on 13 January, rejected the PAICV with all its national symbols and that the flag brought by the combatants, 'imposed by force of arms', in no way reflected the reality of Cape Verde and its history. ${ }^{24}$

The change in the national anthem was more unanimous in party-political terms than the alteration of the flag, particularly for questions of protocol once the unity with Guinea-Bissau had come to an end (the previous anthem had been the same as Guinea's). However, it was more difficult to implement given that no good proposals were presented at the contest to choose an alternative, making it impossible to arrive at a consensus, as Martins (1992), among other, informs us in the newspaper $A$ Semana. ${ }^{25}$ The new anthem, Cântico da Liberdade (Freedom Song), was only approved in 1996, following a vote on a bill presented by the parliamentary benches of the MpD, after that party again won the elections with a qualified majority. ${ }^{26}$ All references to the struggle disappeared, replaced by references to freedom, which now meant also democracy, conquests symbolically exalted by the $\mathrm{MpD}$ as its exclusive property. The reference was also reflected in a new national holiday on 13 January, instituted in 1999 as Freedom and Democracy Day to commemorate the first multi-party elections. 


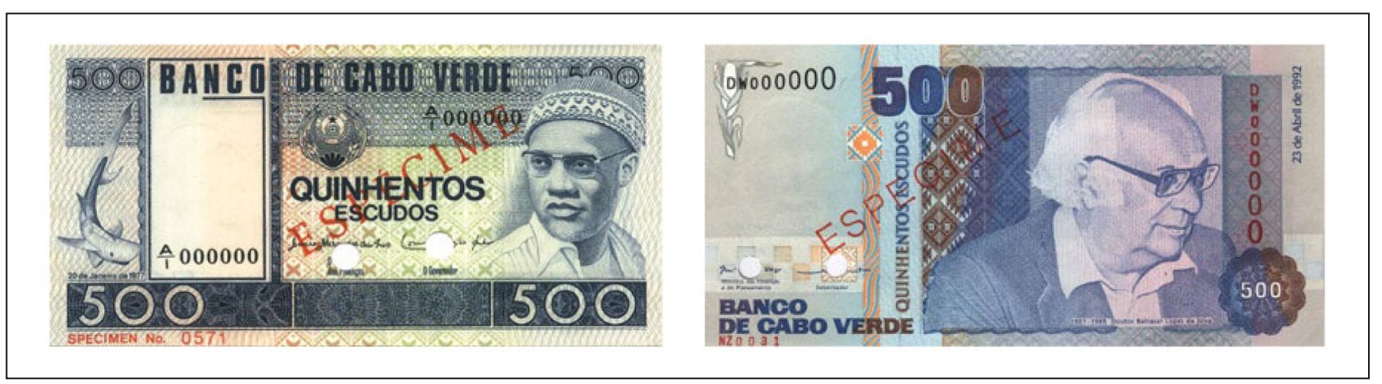

Figure 2. A 1977 banknote with Amílcar Cabral and a 1992 banknote with Baltasar Lopes da Silva. Source: Bank of Cape Verde, http://www.bcv.cv/vPT/Notas\%20e\%20Moedas/Notas/Paginas/Notas.aspx (accessed 3 February 2020).

As regards the currency, this also suffered a process of 'de-Africanization' like other national symbols, as Rego (2015: 77) aptly argues. The notes and coins bearing the image of Cabral and other African revolutionaries were gradually removed from circulation during the 1990s and replaced with motifs of local fauna and flora and effigies of other personalities from the islands (Figure 2). Dating from before the African nationalists, these figures also began to constitute the new basis for citizens to be honoured, more in keeping with the new values of the nation. They were all men from the Creole elite who, despite having been critical of the subaltern status of the Cape Verdean in the archipelago, had not explicitly advocated anticolonialism, Africanness or the independence of the islands. The new iconographic option for the national currency demonstrates how the 'dilution of Africa' (Fernandes, 2002) operated alongside the devaluation of the anticolonial legacy and the de-Cabralization of the national symbols.

Despite this repositioning of Amílcar Cabral in the national space, he was never completely erased from the public memorial landscape of Cape Verde. This was because he was recognized, inside and outside the country, as being greater than the PAIGC. There is, for example, the case of the Amílcar Cabral Memorial. When Niemeyer's proposal to create a cultural centre in his memory was dropped, the intention to monumentalize Cabral was kept on hold. In 1992, the construction of a monument was announced, and the first stone was laid in July 1995 in a ceremony overshadowed by a moment of conflict with a citizen who appeared at the site wielding the former flag of the country, as recorded in the newspaper $A$ Semana (Santana, 1995). The memorial was only inaugurated on 5 July 2000, marking the end of a process marred by impasses and indecision. The statue was offered by the People's Republic of China in the context of a Chinese investment programme in the country, and the whole process took place without the involvement of civil society. The statue itself - in a style that evoked socialist realism - has often been questioned. Mimicking statues of political leaders from Asia, Cabral is shown wearing a thick raincoat and in a rigid pose. It has sometimes been described in interviews and informal conversations as 'like Mao Tse Tung with the head of Cabral'.

Although the anti-anticolonial memoryscape became hegemonic during the 1990s, there has been, in the last two decades, a re-emergence of the memoryscape of the struggle. This is clear not only in the memorial built to honour Amílcar Cabral - despite the criticisms of the style, described above, and more recent controversies about its abandonment or neglect - but also in occasional actions to historically revalorize the figure of the combatants. ${ }^{27}$ Similarly, there has been a diversification in the public and official recognition of actors of the struggle which till then had occupied a relatively subaltern role, such as the case of women (e. g. Coutinho, 2011; Fortes, 2013; Fortes and Raínho, 2018) or former political prisoners (e. g. Fontes, 2018; Lopes, 2010). Moreover, 
roughly in the last decade, the figure of Cabral began to be politically and artistically appropriated by social activists and rappers (Barros and Lima, 2018). This process of mnemonic pluralization - which requires more detailed analysis elsewhere - led to the resurgence of debates around the subject of memory, and the adjustment and accommodation of both memoryscapes. However, rather than producing dynamics of 'agonistic memory' (Bull and Hansen, 2016), they tended to give rise to occasional conflicts of memory, or a more generalized quest for consensus. The latter dynamic runs the risk of not only depoliticizing the past, minimizing the colonial context on which Cape Verde was constructed as a nation, but also producing a composite whose incongruence is revealed whenever it is observed in its totality.

\section{Conclusion: what defines an anti-anticolonial memoryscape}

This article offers an analysis of the anti-anticolonial memoryscape that developed in the 1990s in Cape Verde, breaking with the old memoryscape of the struggle, and seeking to reconfigure national legitimacies in the new political context. There are various reasons that explain this mnemonic transition: first, the defeat of the PAICV in an international context in which liberation movements turned single-party regimes are widely criticized; second, the broad party-political hegemony achieved by the $\mathrm{MpD}$, which enabled it to alter the Constitution and introduce changes in the symbolism and public space, benefitting from this legitimation at the ballot box. Third, it reactivates a diffuse social and political field, where political opponents of the PAIGC/CV, before and after independence, and movements and institutions like the Catholic Church, show themselves available to update and revitalize the Cape Verdean past, reviving pre-existing tensions. Finally, these symbolic and political changes attracted the sympathy of relevant segments of the population, receptive to the reinforcement of an identity ambiguity that Cape Verde establishes in its relationship with Portugal and the colonial heritage. The social availability to accept the mnemonic transition thus suggests that, in addition to breaking the legitimacy of the PAIGC/CV and the regime, the permanence in Cape Verdean society of a colonial imaginary that weaves the postcolonial representations of the nation is also at stake.

The activation of an anti-anticolonial memoryscape is a fundamental part of the affirmation of a new political and ideological hegemony since 1991 . This anti-anticolonial memoryscape extended throughout the decade and redefined names and symbols, creating space, at the same time, to a new national narrative that glorified the earlier heritage from before the liberation struggle and which has echoes to the present. It would consolidate the social reproduction of the ruling class, composed of PAIGC dissidents and a new technocratic generation that is anti-totalitarian in leanings, largely due to the extension of the state in the time of the First Republic and in the investment in study grants (Silva, 2001), in tune with the global discourse about democracy.

But it is crucial to acknowledge that the anti-anticolonial memoryscape is not the mere rehabilitation of the colonial memorial landscape. It is a contemporaneous composite that invokes these elements, some of them strongly associated with a Cape Verdean imaginary produced by the elites, in a new context, not only of economic and political liberalization but also of defeat of the revolutionary emancipatory experiences in the Global South. The hegemony of the anti-anticolonial memoryscape gradually revealed itself over the course of the 2000s and beyond in the presence of some lines of continuity of this imaginary in the political-mnemonic decisions of the new generation of Cape Verdean politicians. The production of memoryscapes 'can therefore be considered a political process, complicit in the reproduction and transformation of power relations' (Kappler, 2017: 140).

The replacement of the 'era of combatants' with the 'era of the cadres' (Anjos, 2004; Furtado, 1997) was accompanied by the ascent of this new memoryscape, anchored not only in 
anti-anticolonial elements such as the disqualification of the armed struggle but also in a symbolic re-reading of the nation, highlighting elements of cultural prestige and continuity with the colonial past of the archipelago. Resulting from exogenous and endogenous dynamics, influences and yearnings, the most obvious examples of this action were the changing of national symbols, and the return of colonial statues and street names back to those that had existed prior to independence. While it is certain that no transition in the memorial landscape operates in a homogeneous or monolithic way, its activation obeyed rhythms of varying intensity and generated social and political contestations, despite achieving success in hegemonic implementation. At a time of profound change, nationally and internationally, the anti-anticolonial memoryscape served not only to reconfigure the place of Cape Verde in the world, but also with(in) itself.

\section{Acknowledgements}

We are very grateful to Crisanto Barros for his helpful feedback in an earlier version of this manuscript, to Bruno Sena Martins for his wise observations in jointed debates and discussions about Cape Verde and to the anonymous reviewers for their insightful comments. We wish to express our special thanks to all the Capeverdean institutions who so generously welcomed us and attended to our queries. Translation of the first draft: Karen Bennett.

\section{Funding}

The author(s) disclosed receipt of the following financial support for the research, authorship and/or publication of this article: The research leading to these results has received funding from the European Research Council (ERC) under the European Union's Horizon 2020 research and innovation programme (Grant Agreement $\mathrm{N}^{\mathrm{o}}$ 715593: 'CROME - Crossed Memories, Politics of Silence: The Colonial-Liberation Wars in Postcolonial Times').

\section{ORCID iD}

Inês Nascimento Rodrigues (iD) https://orcid.org/0000-0001-8088-0201

\section{Notes}

1. For some exceptions to this approach, but with different interpretations to the one proposed here, see Basu (2007), Cole (2001), Kapralski (2017), Phillips and Reyes (2011) and Ullberg (2013).

2. For instance, Cape Verde was a territory whose population was not subjected to the 'Indigenous Statute' as Angola, Mozambique or Guinea were; it was a provider of agents for the colonial administration in other African colonies; and was a place plagued by cyclic droughts and famines that pushed many Cape Verdeans to emigrate in cruel and severe conditions, in particular, but not exclusively, to the cocoa and coffee plantations in S. Tomé and Príncipe. Other migration routes also included the United States and other African and European countries (for more information on the topic of Cape Verdean 'spontaneous' and 'forced' migrations, see Carreira, 1977).

3. On 20 January 1973, Amílcar Cabral was assassinated in Conacry, revealing tensions between Cape Verdeans and Guineans. The involvement of the Portuguese secret police, which years before had already tried to assassinate him, was never properly clarified. On the life and death of Amílcar Cabral, see, among others: Amado (2011); Castanheira (1995); Chabal (1983); Dhada (1993); Mendy (2019); Sousa (2011); Tomás (2007).

4. The one-party regime of the First Republic adopted a political project of a socialist nature that has to be understood on the more general framework of the African independences processes and on anticolonialism and anti-imperialism ideals widespread throughout the continent. Nevertheless, in Cape Verde, this socialist option concurs with a 'pragmatic' politics, where alliances with the Eastern Bloc and African countries coexisted with relations towards the West.

5. Cf. Declarations by the architect João Pedro Martins to the Lusa (2019) news agency. 
6. Although it had been a fundamental part of the anticolonial struggle, the unity of Guinea and Cape Verde became more rhetorical than practical after independence. With their different political and sociocultural situations, the two countries maintained a 'unity' as a political intention inherited from the struggle.

7. Words of the anthem: 'Sun, sweat, the green and the sea, / Centuries of hope and pain; / This is the land of our grandparents! / Fruit of our hands, / Of the flower of our blood: / This is our beloved fatherland. / Long live the glorious fatherland! / The flag of struggle has flowered in the skies. / Forward, against the foreign yoke! / We shall build / On the immortal fatherland / Peace and progress! (x2) / Branches of the same trunk, / Eyes in the same light: / This is the force of our union! / Let the sea and the earth sing / The morning and the sun / That our struggle has borne fruit. [. . .]'.

8. This involved the rehabilitation of musical expressions prohibited during colonialism and despised by the local elites for being more 'African',e.g. funaná, batuque, tabanca (Cidra, 2018; Vasconcelos, 2004).

9. Nino Vieira's coup in Guinea-Bissau in 1980, which deposed Luís Cabral - brother of Amílcar Cabral and intensified the political divisions between Guineans and Cape Verdeans inherited from the liberation struggle, did not lead to significant alterations in this memoryscape. On the contrary, in the immediate aftermath, it actually reinforced the references to the struggle and the context in which it had taken place, as we can see in the November editions of Voz di Povo that year, and also those of January and February 1981.

10. Movement for Democracy $(\mathrm{MpD})$ is a centre-right party affiliated to the Centrist Democrat International. In the context of a liberal democracy, African Party for the Independence of Cape Verde (PAICV) became a centre-left party, member of the Socialist International.

11. In these first elections, the $\mathrm{MpD}$, which appeared some months before, won with a broad margin that enabled them to take more than two-thirds of seats in the National Assembly, a necessary condition for implementing the modifications to the Constitution, carried out in 1992. On 17 February 1991, António Mascarenhas Monteiro beat Aristides Pereira, former President and candidate of the PAICV with 72.6\%. In December, local elections would consolidate the party-political hegemony of the MpD.

12. The term 'mnemonic transition' was previously used by Erll (2017), but with a focus in literature and on the relationship between generation and memory.

13. The immediate perception of these changes introduced by the leadership of the PAICV is acute. In 1990, the President of the Republic, Aristides Pereira, noted that ' 1989 was unpredictable as regards the nature, breadth and speed of political occurrences, particularly in the socialist countries of Europe', obliging us to 'reanalyse the political system' (apud Koudawo, 2001: 98-99).

14. Literary movement associated with the magazine Claridade, which affirms the exceptionality of the Cape Verdean, resulting from his 'creole' nature and the Portuguese contribution in the formation of society (Barros, 2008; Vasconcelos, 2004). This recovering process of figures and movements disconnected from the struggle's heritage aimed, among others, to conciliate the relationship between the regime with socially relevant sectors, namely the elite, who saw these symbols as part of the national heritage (Almada, 2012).

15. See Voz di Povo (1992) and Rego (2015: 77-78). Luís Vaz de Camões was the author of the epic poem The Lusiads in the sixteenth century, and since the end of the nineteenth century, has been constructed as the greatest symbol of Portuguese identity and culture, associated with the overseas adventure. Sá da Bandeira was a Portuguese soldier and statesmen in the nineteenth century.

16. Literature, both fiction and essays, plays an important role in this process of repositioning memories of the past (Fouréré, 2010: 11-12). Between 1992 and 1993, two books were published openly attacking the PAIGC/PAICV and its historic figures, by Silveira (1992) and Cardoso (1993), and also a short novel by Almeida (1992) about one of the most significant episodes in the uprising against the single party, in this case, the opposition in Santo Antão to agrarian reform in August 1981, and in which the agricultural landowners had great influence.

17. In this phase, a decree was issued that obliged the PAICV to prove how it acquired its assets. Mascarenhas Monteiro, during the presidential campaign, claimed in an interview to Daniel Santos (1991a) that 'there was generalized corruption' in the PAIGC in Guinea, and insinuated that the participation of the Cape Verdeans in the armed struggle was not in fact very representative and far removed from the situation experienced in the islands. This, he added, led to the PAICV being punished in the 1991 elections: 'if [the 
people] were given importance to this struggle, the PAICV would continue in power'.

18. Law No. 19/III/87, of 15 August. The Order has three grades, which may be granted to national or foreign citizens, and is awarded to "combatants for the liberation of the Cape Verdean fatherland and all those that contributed significantly to its growth and defence, and for the advent of a juster and more fraternal world', as quoted inRTP Noticias (2005).

19. In accordance with the database of decorations that we were given access to by the Presidency of the Republic of Cape Verde, Mascarenhas Monteiro in his two administrations, awarded other honorific titles (Order of the Dragoeiro, the Jaime Mota medal, the Vulcano Medal and the Medal of Merit) to over 70 men and women, many connected to the dissemination of Cape Verdean culture.

20. Law No. 15/IV/91, of 30 December.

21. Alongside the adjustment on the legal status of the combatant, significant books referencing the experiences of political prisoners and underground fighters were being published, for instance, by Querido (1989), Faustino (1990), Martins (1995) and Lopes (1996).

22. Minutes of the Second Extraordinary Legislative Session, IV Legislature, Plenary Meeting of 21 July 1992. See also Vasconcelos (2004: 184).

23. Interview with Pedro Gregório Lopes, Cidade da Praia, 17 January 2019.

24. Cf. Minutes of the Third Legislative Session, fourth Legislature, Session of 8 June 1992, 482-483. See also Rego (2015: 71-72 and her Chapter 3, on Cape Verdean symbols more generally).

25. Still in 1992, among other applications, there were anthem proposals presented by António Caldeira Marques, president of the União Caboverdiana Independente e Democrática (Independent and Democratic Cape Verdean Union), an opposition party, and by Vasco Martins, one of the great Cape Verdean artists and musicologists (Pina, 1992). Of the poems received, the text of Amílcar Spencer Lopes, President of the National Assembly, was approved, though caricatured for its antiquated and pompous expressions. It was ultimately rejected with the votes of seven deputies from the MpD (Brito, 1992).

26. Words of the anthem: 'Sing, brother / sing, my brother / that Freedom is a hymn / and man is certainty. / With dignity, bury the seed / in the dust of the bare island / in the cliff of life / hope is the size of the sea / that embraces us. / Sentinel of seas and winds / persevering / between stars of the Atlantic / sing the song of freedom [. . . ]'. Written by Amílcar Spencer Lopes and composed by Adalberto Higino Tavares da Silva, both members of MpD. See Barros (1996).

27. Between 2001 and 2011, the presidency of Pedro Pires, former prime minister during the single-party regime, played an important role in this regard, as well as the public reconfiguration of the place of institutions like the Associação de Combatentes da Liberdade da Pátria (Association of the Liberation Struggle Combatants) and the Amílcar Cabral Foundation. As he himself claimed to the magazine Nós Genti Cabo Verde in 2012: 'By standing for President of the Republic I sought to rescue the national liberation struggle, its principles and symbols, taking into account all that happened in the previous ten years [government of the $\mathrm{MpD}$ ]. My victory in the elections is proof that the people also give importance to those principles'.

\section{References}

Almada JLH (2012) Das tragédias históricas do povo caboverdiano e da saga da sua constituição e da sua consolidação como nação crioula soberana. Buala. Available at: http://www.buala.org/pt/a-ler/das-tragedias-historicas-do-povo-caboverdiano-e-da-saga-da-sua-constituicao-e-da-sua-consolida (accessed 25 July 2019).

Almeida G (1992) O dia das calças roladas. Lisbon: Editorial Caminho.

Alves M (1991) Recolocação do Busto do Explorador Serpa Pinto em S. Filipe. Terra Nova, July, 7.

Amado L (2011) Guerra Colonial e Guerra de Libertação Nacional (1950-1974) - o caso da Guiné-Bissau. Lisbon: IPAD.

Anjos JCG (2004) A condição de mediador político-cultural em Cabo Verde: intelectuais e diferentes versões da identidade nacional. Etnográfica 7(2): 273-295.

Barros A (1996) 'Cântico da Liberdade' é o novo hino nacional. Novo Jornal de Cabo Verde, 30 May, 12. 
Barros CA (2012) As elites politico-administrativas cabo-verdianas: 1975- 2008. PhD Thesis, University of Cape Verde/Université Catholique de Louvain-la-Neuve.

Barros M and Lima RW (2018) 20 de janeiro de 1973: assassinato de Amílcar Cabral. In: Cardina M and Martins BS (eds) As Voltas do Passado. A guerra colonial e as lutas de libertação. Lisbon: Tinta-daChina, pp. 240-248.

Barros V (2008) As «sombras» da Claridade. Entre o discurso de integração regional e a retórica nacionalista. In: Torgal LR, Pimenta FT and Sousa JS (eds) Comunidades Imaginadas. Nação e Nacionalismos em África. Coimbra: Imprensa da Universidade de Coimbra, pp. 193-214.

Barros-Varela O (2017) Crítica da Razão Estatal. O Estado Moderno em África nas Relações Internacionais e Ciência Política. Praia, Cape Verde: Pedro Cardoso Livraria.

Basu P (2007) Palimpsest memoryscapes: materializing and mediating war and peace in Sierra Leone. In: De Jong F and Rowlands M (eds) Reclaiming Heritage: Alternative Imaginaries of Memory in West Africa. Walnut Creek, CA: Left Coast Press, pp. 231-259.

Brito K-Z (1992) Sete deputados ventoinhas ajudam a chumbar o hino. Chumbadela. Notícias 30 December, 4.

Bull AC and Hansen HL (2016) On agonistic memory. Memory Studies 9(4): 390-404.

Cahen M (1991) Arquipélagos da alternância: a vitória da oposição nas ilhas de Cabo Verde e São Tomé e Príncipe. Revista Internacional de Estudos Africanos 14-15: 113-154.

Cardoso H (1993) O Partido único em Cabo Verde: um assalto à esperança. Praia, Cape Verde: Imprensa Nacional de Cabo Verde.

Carreira A (1977) Migrações nas ilhas de Cabo Verde. Lisbon: Universidade Nova de Lisboa.

Castanheira JP (1995) Quem Mandou Matar Amílcar Cabral. Lisbon: Relógio D’Água.

Chabal P (1983) Amilcar Cabral. Revolutionary leadership and people's war. London: Cambridge University Press.

Cidra R (2018) Cabral, popular music and the debate on Cape Verdean creoleness. Postcolonial Studies 21(4): $2-19$.

Cole J (2001) Forget Colonialism? Sacrifice and the Art of Memory in Madagascar. Berkeley, CA; Los Angeles, CA: University of California Press.

Coutinho A (2011) Mulheres na «sombra»: as cabo-verdianas e a luta de libertação nacional. In: Silva C and Fortes C (eds) As mulheres em Cabo Verde: experiências e perspectivas. Praia, Cape Verde: UNICV, pp. 39-47.

Coutinho A (2015) O processo de descolonização de Cabo Verde. In: Rosas F, Machaqueiro M and Oliveira PA (org.) O Adeus ao Império. 40 Anos de Descolonização Portuguesa. Lisbon: Vega, pp. 125-140.

Davis P (2013) Memoryscapes in transition: Black history museums, new south narratives, and urban regeneration. Southern Communication Journal 78(2): 107-127.

De Jong F (2008) Recycling recognition: the monument as Objet Trouvé of the Postcolony. Journal of Material Culture 13(2): 195-214.

Dhada M (1993) Warriors at Work: How Guinea Was Really Set Free. Boulder, CO: University Press of Colorado.

Edensor T (1997) National identity and the politics of memory: remembering Bruce and Wallace in symbolic space. Environment and Planning 29: 175-194.

Erll A (2017) Fictions of generational memory: Caryl Phillips's in the falling snow and Black British writing in times of mnemonic transition. In: Bond L, Craps S and Vermeulen P (eds) Memory Unbound: Tracing the Dynamics of Memory Studies. New York: Berghahn Books, pp. 109-130.

Évora R (2004) Cabo Verde: a abertura política e a transição democrática. Praia, Cape Verde: Spleen Edições.

Faustino M (1990) Jorge Querido: subsidios sob suspeita. Mindelo, Cape Verde: Ilhéu Editora.

Fernandes G (2002) A diluição da África: uma interpretação da saga identitária cabo-verdiana no panorama político (pós)colonial. Florianópolis, Brazil: UFSC.

Fontes E (2018) Uma história inacabada. Praia, Cape Verde: Pedro Cardoso Livraria. 
Fortes C and Raínho R (2018) 16 de julho de 1967: Início das emissões da Rádio Libertação, do PAIGC. In: Cardina M and Martins BS (eds) As Voltas do Passado. A guerra colonial e as lutas de libertação. Lisbon: Tinta-da-China, pp. 178-183.

Fortes P (2013) Minha passagem. Praia, Cape Verde: Fundação Amílcar Cabral.

Fouréré M-A (2010) Memory through the prism of politics. Cahiers d'études africaines 197: 5-24.

Furtado CA (1997) Génese e (Re)Produção da Classe Dirigente em Cabo Verde. Praia, Cape Verde: I.C.L.

Furtado CA (2016) Cabo Verde e as quatro décadas da independência: dissonâncias, múltiplos discursos, reverberações e lutas por imposição de sentido à sua história recente. Estudos Ibero-Americanos 42(3): $855-887$.

Górny K and Górna A (2019) After decolonization: changes in the urban landscape of Platô in Praia, Cape Verde. Journal of Urban History 45(6): 1103-1130.

Kappler S (2017) Sarajevo's ambivalent memoryscape: spatial stories of peace and conflict. Memory Studies 10(2): 130-143.

Kapralski S (2017) Jews and the holocaust in Poland's memoryscapes: an inquiry into transcultural amnesia. In: Andersen TS and Tornquist-Plewa B (eds) The Twentieth Century in European Memory. Leiden: Brill, pp. 170-197.

Koudawo F (2001) Cabo Verde e Guiné-Bissau. Da democracia revolucionária à democracia liberal. Bissau, Guinea-Bissau: INEP.

Lopes JV (1996) Cabo Verde. Os Bastidores da Independência. Praia, Cape Verde: Spleen Edições.

Lopes JV (2010) Tarrafal: Chão Bom: memórias e verdades, 2 vol. Praia, Cape Verde: IIPC.

Lusa (2019) Cabo Verde estaria na rota do turismo arquitetónico com memorial a Cabral de Niemeyer. Available at: https://www.dn.pt/lusa/interior/cabo-verde-estaria-na-rota-do-turismo-arquitetonico-commemorial-a-cabral-de-niemeyer-10559397.html (accessed 1 August 2019).

Madeira JP (2018) Nação e Identidade. A singularidade de Cabo Verde. Praia, Cape Verde: Pedro Cardoso Livraria.

Martins JVC (1992) Constituição Nova. Hino Antigo. A Semana, 17 July, 3.

Martins P (1995) Testemunho de um Combatente. Praia, Cape Verde: Instituto Camões/Centro Cultural Português.

Mendy PK (2019) Amílcar Cabral. Nationalist and Pan-africanist Revolutionary. Athens, OH: Ohio University Press.

Molden B (2016) Resistant pasts versus mnemonic hegemony: on the power relations of collective memory. Memory Studies 9(2): 125-142.

Monteiro EF (2016) Crioulidade, colonialidade e género: as representações de Cabo Verde. Revista Estudos Feministas 24(3): 983-996.

Muzaini H (2006) Producing/consuming memoryscapes: the genesis/politics of Second World War commemoration in Singapore. GeoJournal 66(3): 211-222.

Muzaini H (2014) The afterlives and memory politics of the Ipoh Cenotaph in Perak, Malaysia. Geoforum 54: $142-150$.

Muzaini H and Yeoh BSA (2016) Contested Memoryscapes. The Politics of Second World War Commemoration in Singapore. London; New York: Routledge.

Nós Genti Cabo Verde (2012) Pedro Pires - O exemplo da boa governação no continente Africano. Available at: http://nosgenti.com/o-exemplo-da-boa-governacao-no-continente-africano/ (accessed 19 August 2019).

Paasi A (2016) Dancing on the graves: independence, hot/banal nationalism and the mobilization of memory. Political Geography 54: 21-31.

Phillips KR and Reyes GM (eds) (2011) Global Memoryscapes: Contesting Remembrance in a Transnational Age. Tuscaloosa, AL: University of Alabama Press.

Pina A (1992) A propósito do novo hino nacional. A Semana, 30 October, 6.

Querido J (1989) Cabo Verde. Subsídios para a História da nossa Luta de Libertação. Lisbon: Vega.

Raimundo G (1991) Sem foguetório e a toque da Banda Municipal. Diogo Gomes sai da Clandestinidade. Voz di Povo, 26 March, 4. 
Rego M (2015) The Dialogic Nation of Cape Verde: Slavery, Language and Ideology. New York; London: Lexington Books.

RTP Notícias (2005) Manuel Alegre apresenta mandatários distritais em Coimbra. Available at: https://www. rtp.pt/noticias/pais/manuel-alegre-apresenta-mandatarios-distritais-em-coimbra_n20200 (accessed 29 July 2019).

Sanches ER (2018) Party Systems in Young Democracies: Varieties of Institutionalization in Sub-Saharan Africa. London; New York: Routledge.

Santana DC (1995) Memorial Amílcar Cabral no Taiti. Colocada a primeira pedra. . . quem coloca agora a segunda. A Semana, 10 July, 5.

Santos D (1991a) «Sou um desertor especial». Voz di Povo, 16 February, 7.

Santos J (1991b) O PAICV e a lei de Parkinson. Voz di Povo, 27 July, 2.

Silva AC (1997) O Processo Caboverdiano de Transição para a Democracia. Master Thesis, ISCTE, Lisbon.

Silva AC (2001) O Nascimento do Leviatã Crioulo: esboços de sociologia política. Cadernos de Estudos Africanos 1: 53-68.

Silva AC (2004) Cabo Verde: Desafios económicos e a estruturação do Estado. Do Estado-Providência (sem contribuintes) ao liberalismo sem empresários. O Ciclo da I República. In: VIII Congresso LusoAfro-Brasileiro de Ciências Sociais - A Questão Social no Novo Milénio, Coimbra, 16-18 September. Available at: https://www.ces.uc.pt/lab2004/inscricao/pdfs/grupodiscussao5/AntonioLeaoSilva.pdf (accessed 30 July 2019).

Silveira O (1992) A tortura em nome do partido único. O PAICV e a sua polícia política. Mindelo, Cape Verde: Terra Nova and Ponto\&Vírgula.

Sousa JS (2011) Amílcar Cabral (1924-1973): vida e morte de um revolucionário africano. Lisbon: Nova Vega.

Tomás A (2007) O fazedor de utopias: uma biografia de Amílcar Cabral. Lisbon: Tinta-da-China.

Ullberg S (2013) Watermarks: Urban Flooding and Memoryscape in Argentina. Stockholm: Acta Universitatis Stockholmiensis.

Vasconcelos J (2004) Espíritos Lusófonos numa ilha crioula: Língua, poder e identidade em São Vicente de Cabo Verde. In: Carvalho C and Cabral JP (org.) A persistência da história: Passado e Contemporaneidade em África. Lisbon: Imprensa de Ciências Sociais, pp. 149-190.

Voz di Povo (1992) Bustos de Camões e Sá da Bandeira repostos no Mindelo. 25 August, 4.

\section{Author biographies}

Miguel Cardina is a Historian and Senior Researcher at the Centre for Social Studies of the University of Coimbra. He is the Coordinator of the project 'CROME-Crossed Memories, Politics of Silence. The ColonialLiberation Wars in Postcolonial Times' (2017-2022), financed by the European Research Council (ERC). He works on colonialism, anticolonialism and the colonial wars; political ideologies in the sixties and seventies; and the dynamics between history, memory and power.

Inês Nascimento Rodrigues is a Researcher at the Centre for Social Studies of the University of Coimbra, where she develops her investigation within 'CROME-Crossed Memories, Politics of Silence: The ColonialLiberation Wars in Postcolonial Times'. She holds a PhD in Postcolonialisms and Global Citizenship and is the author of several publications, mainly concerning memory studies, postcolonial theories, colonial violence and the debates surrounding the commemoration of liberation struggles. 